\title{
Attachment Strategies and Neuroendocrine Biomarkers in Obese Children
}

\author{
Estratégias de Vinculação e Biomarcadores \\ Neuroendócrinos em Crianças Obesas
}

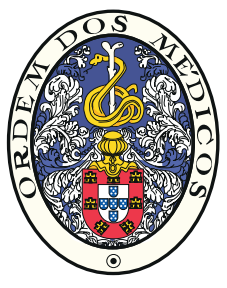

Inês PINTO $\triangle^{1,2,3}$, Simon WILKINSON ${ }^{4,5}$, Daniel VIRELLA ${ }^{6}$, Marta ALVES ${ }^{6}$, Conceição CALHAU $^{7,8}$, Rui COELHO
Acta Med Port 2016 May;29(5):332-339 • http://dx.doi.org/10.20344/amp.6826

\section{ABSTRACT}

Introduction: Quality of the parent-infant relationship influences the mechanisms of development of the child's physiological stress regulation. This study explored associations between attachment strategies and both cortisol and thyroid stimulating hormone, hypothesized to be respectively a potential mediator and a potential intervening variable of the mother-child relationship in obese children.

Material and Methods: A sample of 83 obese children (46 boys), aged 10.9 (1.8) years was recruited from a child obesity clinic. Obesity was defined by body mass index percentile adjusted for age and sex. Metabolic biomarkers were measured by routine methods. Attachment strategies were assessed with self and parent-report questionnaires. Family functioning was assessed with parent-reported questionnaires (FACES-III). Multivariate linear regression analyses were performed.

Results: Type A, avoidant attachment strategies, had significant positive association with thyroid stimulating hormone levels and negative association with cortisol levels $\left(R^{2}=0.352\right)$. Type $B$, secure attachment strategies, had significant positive associations with both hypothyroidism and body mass index percentile $\left(R^{2}=0.541\right)$. "Insecure attachment" (types A and C combined) strategies showed some evidence of positive association with thyroid stimulating hormone $\left(R^{2}=0.250\right)$.

Discussion: These findings suggest that there may be commonalities in the regulation of hypothalamic-pituitary-adrenal and hypothalamic-pituitary-thyroid axes. Processes involved in development of the type A attachment strategy appear to be associated with effects on the regulatory mechanisms of the hypothalamic-pituitary-adrenal axis.

Conclusions: In obese children, different attachment strategies are associated with diverse metabolic profiles. How this may contribute to developing differentiated treatment approaches remains to be explored.

Keywords: Child; Hypothalamo-Hypophyseal System; Object Attachment; Pediatric Obesity; Pituitary-Adrenal System; Stress, Psychological; Thyrotropin.

\section{RESUMO}

Introdução: A qualidade da relação pais-filho influencia o desenvolvimento do sistema fisiológico de regulação do stress da criança. Exploraram-se eventuais associações entre estratégias de vinculação e o cortisol e a hormona estimulante da tiróide, respectivamente como possíveis mediador e variável interveniente na relação mãe-filho, na criança obesa.

Material e Métodos: Foi recrutada na Consulta de Obesidade uma amostra de conveniência de 83 crianças obesas com 10,9 $(1,8)$ anos de idade (46 rapazes). A obesidade foi definida pelo percentil do índice de massa corporal para idade e género e os biomarcadores neuroendócrinos foram medidos pelos métodos de rotina. As estratégias de vinculação foram avaliadas através dos questionários (IACA) para pais e crianças. O funcionamento familiar foi classificado através do preenchimento pelos pais do FACES-III. Foram analisados modelos multivariáveis de regressão linear.

Resultados: As estratégias de vinculação insegura do tipo evitante (tipo A) apresentaram uma associação significativa positiva com os níveis de hormona estimulante da tiróide e negativa com os níveis de cortisol $\left(R^{2}=0,352\right)$. As estratégias de vinculação segura (tipo B) associaram-se positivamente ao hipotiroidismo e ao percentil de índice de massa corporal, ambas com significado estatístico $\left(R^{2}=0,541\right)$. As estratégias de vinculação insegura apresentaram alguma evidência de associação positiva com a hormona estimulante da tiróide $(\mathrm{R} 2=0,250)$.

Discussão: Estes achados sugerem a existência de factores comuns na regulação dos eixos hipotálamo-hipófise-adrenal e hipotálamo-hipófise-tiróide. Os processos envolvidos no desenvolvimento das estratégias de vinculação do tipo A parecem associar-se aos mecanismos regulatórios do eixo HPA.

Conclusão: Diferentes estratégias de vinculação estão associadas a diferentes padrões metabólicos em crianças obesas. Desconhece-se qual a sua contribuição para o desenvolvimento e diferenciação da abordagem terapêutica.

Palavras-chave: Apego ao Objecto; Criança; Obesidade Pediátrica; Sistema Hipotálamo-Hipofisário; Sistema Hipófise-Suprarrenal; Stress Psicológico; Tireotropina.

\footnotetext{
1. Department of Child and Adolescent Psychiatry. Hospital Beatriz Ângelo. Loures. Portugal.

2. Department of Psychiatry and Mental Health. Faculty of Medicine. University of Porto. Porto. Portugal.

3. Hospital Dona Estefânea. Centro Hospitalar Lisboa Central. Lisboa. Portugal.

4. Adolescent Psychiatric Section. Lørenskog University Hospital. Oslo. Norway.

5. Department of Research and Development. Division of Mental Health. Akershus University Hospital. Oslo. Norway.

6. Epidemiology and Statistics Office of the Research Unit. Centro Hospitalar de Lisboa Central. Lisboa. Portugal.

7. Nutrição e Metabolismo. Nova Medical School. Faculdade de Ciências Médicas. Universidade Nova de Lisboa. Lisboa. Portugal.

8. Center for Research in Health Technologies and Information Systems (CINTESIS). University of Porto. Porto. Portugal.

9. Department of Neurosciences and Mental Health. Faculdade de Medicina da Universidade do Porto. Porto. Portugal.

10. Institute for Research and Innovation inHealth (i3S). University of Porto. Porto. Portugal.

$\triangle$ Autor correspondente: Inês Pinto. inescopinto@gmail.com

Recebido: 25 de julho de 2015 - Aceite: 28 de dezembro de 2015 | Copyright $\odot$ Ordem dos Médicos 2016
} 


\section{INTRODUCTION}

The child-parent relationship plays a major role in the child's early life, influencing socio-emotional development, emotion regulation abilities and leading to development of particular attachment strategies. ${ }^{1-4}$ The quality of the relationship influences both behavioral and metabolic regulation systems as they are activated in stressful contexts. ${ }^{5}$ Obese children's attachment strategies have not received much attention. There is evidence that variance in hypothalamic-pituitary-adrenal (HPA) axis activity varies with weight. ${ }^{6}$ In the present study, the quality of attachment was examined in relation to various neuroendocrine biomarkers, including cortisol and thyroid stimulating hormone (TSH).

Methods for evaluating pre-pubertal children's attachment strategies have not been well developed, with the result that there is little information about any relations between metabolic indicators and attachment strategies in this age group. Hypotheses have been developed based on research in younger children. ${ }^{7}$

Secure attachment (type B) is associated with the child's approach to its mother at times of need, and is interpreted as basic trust in the mother's availability and responsiveness. The mother has the child 'in mind' and she is available at times of child stress. Through contingent responsiveness, she enables her child to regulate his state, first via her direct handling of the child and subsequently through enabling her child's self-contained management of his affect - an external process facilitates internalizing of the affect regulation. In contrast, the child of a consistently insensitive and unresponsive mother does not learn to expect its mother to be available in stressful situations and develops an insecure-avoidant attachment (type A). On the other hand, the inconsistently available mother elicits escalating displays of affect in her child, who forces his mother to respond on the basis of an intermittent reinforcement schedule, but remains ambivalent about close contact when proffered as it was only elicited under duress (insecure-resistant attachment, type C). The type A child focuses on the environment at the moment of reunion, ignoring the mother or appearing to approach her but with objects between them, preventing the distress of potentially not being acknowledged. The reunion behavior of the type $\mathrm{C}$ child is characterized by anxious contact seeking and clinging, while, at the same time, ambivalently resisting contact with his mother.

It appears that only little or no excess adrenocortical activation is observed in a securely attached child when separated from his mother. $5,8,9$ The findings in the insecure-avoidant and insecure-resistant attachment groups are inconsistent. In some studies, both insecure groups were found to have elevated cortisol levels, ${ }^{8}$ others found increased cortisol levels only for insecure-resistant children. ${ }^{10}$ These may to some degree reflect disagreements about how to classify particular behavioural strategies. Nevertheless it is theoretically coherent to expect elevated cortisol levels with type $\mathrm{C}$, as those children are exposed to chronic unpredictable stress, their parents responding to their distress only intermittently. Such findings point to cortisol levels being, at least partly, affected by the caregiving environment. ${ }^{11,12}$

Evidence of the contribution of caregiving processes to the development and maintenance of obesity has been mixed. $6,13,14$ The environmental factors contributing to cortisol reactivity and associated neuroendocrine changes have yet to be documented in people with obesity. ${ }^{13}$ Subtyping insecure attachment may help explain variability in cortisol reactivity, since inter-individual variability in HPAaxis activity appears to vary with type $A$ and $C$ strategies. ${ }^{15,16}$

Cortisol, a product of HPA-axis activation, inhibits its own release through negative feedback actions at the level of the pituitary and other brain areas. Previous data indicate that glucocorticoids can inhibit the hypothalamic-pituitarythyroid (HPT) axis, at the level of the hypothalamus and pituitary. ${ }^{17}$ Because both the HPA and HPT axes are stress responsive endocrine systems, it has been of interest to determine if there is any cross-regulation or communication between the HPA and HPT axes.

There are few Portuguese studies correlating cortisol and TSH levels with neuropsychiatric conditions for children of this age. Some independent studies of Portuguese cohorts have been published relating interrelations between the pituitary-thyroid axis and major neurosignaling systems involved in schizophrenia's pathophysiology. The available evidence supports that thyroid hormones deregulation is a common feature in schizophrenia and the fine-tuning of crucial brain networks warrants thyroid hormones homeostasis. ${ }^{17}$

Obesity has been associated with changes in HPA and HPT-axis activity, attributed to disturbance of the feedback system. ${ }^{18}$ The feedback loop is crucial in recovery from stress, which in turn is essential for healthy physiological and behavioral regulation.

The current study is part of the project "Roots of Early Obesity", 19 aiming at a wide ranging assessment of prepubertal obese children. We analyzed the hypothesis of an association between the strategies of attachment of obese children and their neuroendocrine biomarkers.

\section{MATERIAL AND METHODS \\ Sample and procedure}

A convenience sample of children attending the Child Obesity Paediatric Unit of a Tertiary Paediatric Hospital in Greater Lisbon, was drawn from pre-pubertal obese children recruited for the project "Roots of Early Obesity". Participants were those for whom detailed anthropometric information and behavioral measurements of the child's development were feasible to collect. Parental written, informed consent was obtained. The project was approved by the Hospital Medical Ethics Committee.

\section{Measures \\ Attachment strategies}

The attachment strategies of children were assessed 
using "IVIA - inventário sobre a vinculação na infância e adolescência" (IACA - Inventory of Attachment in Childhood and Adolescence), a set of parent-reported and selfreported questionnaires, originally developed and validated in Portugal. ${ }^{20}$ IVIA was designed to classify child-caregiver attachment strategies in childhood and adolescence, from 7 to 17 years of age. It categorizes attachment strategies as secure (type $B$ ), insecure-avoidant (type A), or insecureresistant (type $C$ ). IVIA does not consider type $D$, insecuredisorganized/disoriented strategy, ${ }^{21}$ following instead the dynamic maturational model of attachment and adaptation (DMM) classificatory system. ${ }^{22,23}$ Satisfactory psychometric properties were reported..$^{20}$

\section{Family functioning}

Family functioning and typology were assessed using FACES III (family adaptation and cohesion scale), ${ }^{24}$ a parent-reported questionnaire, validated for Portugal. ${ }^{25}$ Only one parent per child was surveyed, most often the mother. This self-reported tool is a 20 -item Lykert type questionnaire that evaluates 2 major dimensions on the circumplex model: cohesion and family adaptation. Reliability for the cohesion is 0.78 and for the adaptability is $0.70 .^{25}$

This tool assesses the degree to which family members are adaptive and connected to each other. The circumplex model is a classification system with 16 family types, organized in three general types: balanced, mid-range, and extreme. The family adaptability is classified in four levels: rigid, structured, flexible, and chaotic. The two central levels (structured and flexible) are considered as balanced family adaptability and the two extreme levels (rigid and chaotic) are considered as unbalanced family adaptability. The family cohesion is classified in four levels: disengaged, separated, connected, and enmeshed. The two central levels (separated and connected) are considered as balanced family cohesion and the two extreme levels (disengaged and enmeshed) are considered as unbalanced family cohesion. ${ }^{24}$ According to the curvilinear hypothesis, balanced levels of cohesion and adaptability (low to high levels) tend to reflect healthier family functioning, while unbalanced levels of cohesion and adaptability (very low or very high levels) tend to reflect more problematic family functioning. ${ }^{24}$ The general family types, determined by adaptability and cohesion scores, are balanced, mid-range, and extreme, according to Olson. ${ }^{24}$

\section{Metabolic assessment}

Height, weight, waist circumference, blood pressure and heart rate were measured following standardized protocols. Body mass index (BMI) (kg. $\left.\mathrm{m}^{-2}\right)$ was calculated using height and weight. Obesity was defined as $\mathrm{BMI} \geq 95^{\text {th }}$ age and gender-specific percentile. ${ }^{26}$ Blood pressure was measured three times and the third reading was recorded. ${ }^{27}$ Age and gender-specific percentiles were used. ${ }^{27}$

Table 1 - Descriptives of the neuroendocrine and metabolic indicators

\begin{tabular}{|c|c|c|c|c|}
\hline Parameter (n) & Mean (SD) & Median & Min.- max. & $25^{\text {th }} P-75^{\text {th }} P$ \\
\hline Glucose (mg/dL) (53) & $93.96(9.356)$ & 93.0 & $71-120$ & $89.0-98.0$ \\
\hline Insulin (U/mL) (39) & $14.45(9.85)$ & 13.3 & $0.28-52.95$ & $7.99-16.50$ \\
\hline Triglycerides (mg/dL) (48) & $97.5(39.85)$ & 89.0 & $33-187$ & $68.0-129.75$ \\
\hline Cholesterol (mg/dL) (50) & $162.7(31.52)$ & 166.0 & $49-227$ & $145.0-184.5$ \\
\hline $\mathrm{HDL}(\mathrm{mg} / \mathrm{dL})(47)$ & $48.6(14.24)$ & 45.0 & $24-91$ & $38.0-57.0$ \\
\hline LDL (mg/dL) (45) & $108.7(23.78)$ & 110.0 & $59-167$ & $96.5-120.0$ \\
\hline $\operatorname{ALT}(\mathrm{U} / \mathrm{L})(46)$ & $27.35(23.86)$ & 22.5 & $11-167$ & $16.75-30.0$ \\
\hline AST (U/L) (44) & $23.75(7.59)$ & 23.5 & $12-56$ & $18.25-26.0$ \\
\hline TSH $(\mu \mathrm{IU} / \mathrm{mL})(52)$ & $2.8(1.21)$ & 2.68 & $0.72-5.92$ & $1.7-3.5$ \\
\hline T4 (ng/dl) (49) & $1.3(2.19)$ & 1.0 & $0.59-16.20$ & $0.8-1.2$ \\
\hline ACTH (pg/mL) (49) & $26.4(16.94)$ & 20.65 & $5.35-105.0$ & $16.6-33.2$ \\
\hline Cortisol ( $\mu \mathrm{g} / \mathrm{dL})(53)$ & $10.7(5.58)$ & 8.8 & $3.3-29.0$ & $6.7-13.5$ \\
\hline Dopamine urine $(\mu \mathrm{g} / \mathrm{dL})(15)$ & $248.0(136.60)$ & 240.85 & $45.0-513.8$ & $155.4-354.0$ \\
\hline Dopamine plasma $(\mu \mathrm{g} / \mathrm{dL})(11)$ & $79.65(88.49)$ & 36.7 & $6.0-240.85$ & $23.6-198.25$ \\
\hline Epinephrine urine $(\mu \mathrm{g} / \mathrm{dL})(15)$ & $6.5(7.70)$ & 5.99 & $0.5-32.5$ & $3.4-6.99$ \\
\hline Epinephrine plasma ( $\mu \mathrm{g} / \mathrm{dL})(11)$ & $4.5(9.61)$ & 0.48 & $0.09-32.54$ & $0.3-6.1$ \\
\hline Norepinephrine urine $(\mu \mathrm{g} / \mathrm{dL})(15)$ & $34.6(27.19)$ & 28.1 & $5.9-105.8$ & $15.9-56.2$ \\
\hline Norepinephrine plasma $(\mu \mathrm{g} / \mathrm{dL})(11)$ & $9.8(11.68)$ & 4.05 & $0.8-39.0$ & $2.4-19.11$ \\
\hline
\end{tabular}

Glucose: basal plasma glucose; Max.: maximum; Min.: minimum; n: number of assessed children; P: percentile; SD: standard deviation 
As part of the "Roots of Early Obesity"19 project, fasting blood samples were drawn at 8 a.m through an indwelling i.v. catheter, after 45 min of rest. Children were considered healthy and had not taken any medication. Plasma cortisol, glucose, insulin, high density lipoprotein (HDL) and low density lipoprotein (LDL) cholesterol, triglycerides, catecholamines, TSH and T4 were measured using the standard procedures of the Clinical Pathology Laboratory of the institution. TSH $\geq 3.1 \mu \mathrm{lU} / \mathrm{mL}$ was considered as laboratorial evidence of hypothyroidism.

\section{Statistical analyses}

To explore the association between attachment strategies (modeled as nominal variables), age, gender, family functioning and neuroendocrine and metabolic assessment measures, univariable linear regression models were applied.

Strategies types $\mathrm{A}$ and $\mathrm{C}$ were combined to provide an "insecure attachment" group (a standard practice using the Berkeley system for attachment classification associated with Mary Main), for multivariable analysis. Variables that had a significant association with each attachment strategy

Table 2A - Associations between attachment strategies (secure and insecure) and anthropometric, familiar and neuroendocrine variables (univariable analysis)

\begin{tabular}{|c|c|c|c|c|}
\hline & \multicolumn{2}{|c|}{$\begin{array}{l}\text { Secure attachment } \\
\text { (type B) }\end{array}$} & \multicolumn{2}{|c|}{ "Insecure attachment" } \\
\hline & $\begin{array}{c}\beta \text {-estimate } \\
(95 \% \mathrm{Cl})\end{array}$ & $p$-value & $\begin{array}{c}\beta \text {-estimate } \\
(95 \% \mathrm{Cl})\end{array}$ & $p$-value \\
\hline Gender (boys) & $\begin{array}{c}-0.007 \\
(-0.095 ; 0.082)\end{array}$ & 0.882 & $\begin{array}{c}0.072 \\
(-0.069 ; 0.213)\end{array}$ & 0.309 \\
\hline BMI percentile & $\begin{array}{c}0.035 \\
(-0.168 ; 0.237)\end{array}$ & 0.731 & $\begin{array}{c}0.119 \\
(-0.200 ; 0.439)\end{array}$ & 0.457 \\
\hline Family functioning (high level) & $\begin{array}{c}0.027 \\
(-0.078 ; 0.131)\end{array}$ & 0.610 & $\begin{array}{c}-0.012 \\
(-0.179 ; 0.154)\end{array}$ & 0.883 \\
\hline Hypothyroidism & $\begin{array}{c}0.063 \\
(-0.053 ; 0.180)\end{array}$ & 0.277 & $\begin{array}{c}-0.001 \\
(-0.186 ; 0.184)\end{array}$ & 0.989 \\
\hline $\mathrm{TSH}(\mu \mathrm{IU} / \mathrm{mL})$ & $\begin{array}{c}-0.001 \\
(-0.051 ; 0.049)\end{array}$ & 0.962 & $\begin{array}{c}0.069 \\
(-0.006 ; 0.144)\end{array}$ & 0.072 \\
\hline ACTH $(\mathrm{pg} / \mathrm{mL})$ & $\begin{array}{c}-0.003 \\
(-0.005 ; 0.000)\end{array}$ & 0.061 & $\begin{array}{c}-0.005 \\
(-0.010 ;-0.001)\end{array}$ & 0.030 \\
\hline Cortisol ( $\mu \mathrm{g} / \mathrm{dL})$ & $\begin{array}{c}0.002 \\
(-0.008 ; 0.012)\end{array}$ & 0.672 & $\begin{array}{c}-0.016 \\
(-0.030 ;-0.002)\end{array}$ & 0.026 \\
\hline
\end{tabular}

ACTH: adrenocorticotropic hormone; BMI: body mass index; Cl: confidence interval; TSH: thyroid-stimulating hormone

Table 2B - Associations between attachment strategies (avoidant and resistant) and anthropometric, familiar and neuroendocrine variables (univariable analysis)

\begin{tabular}{|c|c|c|c|c|}
\hline & \multicolumn{2}{|c|}{$\begin{array}{c}\text { Avoidant attachment } \\
\text { (type A) }\end{array}$} & \multicolumn{2}{|c|}{$\begin{array}{l}\text { Resistant attachment } \\
\text { (type C) }\end{array}$} \\
\hline & $\begin{array}{c}\beta \text {-estimate } \\
(95 \% \mathrm{Cl})\end{array}$ & $p$-value & $\begin{array}{c}\beta \text {-estimate } \\
(95 \% \mathrm{Cl})\end{array}$ & $p$-value \\
\hline Gender (boys) & $\begin{array}{c}0.056 \\
(-0.028 ; 0.140)\end{array}$ & 0.187 & $\begin{array}{c}0.016 \\
(-0.075 ; 0.107)\end{array}$ & 0.724 \\
\hline BMI percentile & $\begin{array}{c}0.141 \\
(-0.050 ; 0.332)\end{array}$ & 0.144 & $\begin{array}{c}-0.021 \\
(-0.226 ; 0.183)\end{array}$ & 0.834 \\
\hline Family functioning (high level) & $\begin{array}{c}-0.051 \\
(-0.153 ; 0.051)\end{array}$ & 0.316 & $\begin{array}{c}0.039 \\
(-0.066 ; 0.143)\end{array}$ & 0.456 \\
\hline Hypothyroidism & $\begin{array}{c}-0.012 \\
(-0.122 ; 0.097)\end{array}$ & 0.820 & $\begin{array}{c}0.011 \\
(-0.112 ; 0.134)\end{array}$ & 0.855 \\
\hline TSH $(\mu \mathrm{IU} / \mathrm{mL})$ & $\begin{array}{c}0.048 \\
(0.004 ; 0.091)\end{array}$ & 0.034 & $\begin{array}{c}0.021 \\
(-0.030 ; 0.073)\end{array}$ & 0.405 \\
\hline ACTH $(p g / m L)$ & $\begin{array}{c}-0.003 \\
(-0.006 ; 0.000)\end{array}$ & 0.032 & $\begin{array}{c}-0.021 \\
(-0.005 ; 0.001)\end{array}$ & 0.142 \\
\hline Cortisol ( $\mu \mathrm{g} / \mathrm{dL})$ & $\begin{array}{c}-0.008 \\
(-0.016 ; 0.001)\end{array}$ & 0.075 & $\begin{array}{c}-0.008 \\
(-0.017 ; 0.001)\end{array}$ & 0.069 \\
\hline
\end{tabular}

ACTH: adrenocorticotropic hormone; BMl: body mass index; Cl: confidence interval; TSH: thyroid-stimulating hormone 
were included in multivariable explanatory models tested by multiple linear regression, in which gender, BMI percentile and the classification of family functioning were always included. A $p$ - value $\leq 0.05$ was considered statistically significant. Statistical analysis was carried out using Statistical Package for the Social Science for Windows version 22.0 (SPSS Inc, Chicago IL).

\section{RESULTS}

From 83 recruited pre-pubertal children, 73 children (40 boys) with all the required data were included. The sample had a mean age $10.86(S D=1.8)$ years. The $B M l$ was above the $97^{\text {th }}$ percentile in 68 children $(93 \%)$. The mean waist circumference, measured in 34 children, was $88.1 \mathrm{~cm}$ $(\mathrm{SD}=13.99 \mathrm{~cm})$. Systolic blood pressure was above the $95^{\text {th }}$ percentile in 20 out of 59 children (33.9\%).

The distribution of the measurements of the neuroendocrine values and metabolic indicators is presented in Table 1.

From the univariable analysis between attachment strategies and the neuroendocrine and metabolic indicators, $\mathrm{ACTH}$, cortisol, TSH and hypothyroidism were identified as potentially associated with secure attachment (type B), "insecure attachment" (Table 2A) and avoidant attachment (type A) (Table 2B). No association was found for resistant attachment (type C) (Table 2B).

The main results of multivariable analysis of the explanatory models for the attachment strategies are shown in Table 3. Type A, avoidant attachment strategies, had significant positive association with $\mathrm{TSH}$ levels and negative association with cortisol levels $\left(R^{2}=0.352\right)$. Type $B$, secure attachment strategies, had significant positive associations with both hypothyroidism and BMI percentile $\left(R^{2}=0.541\right)$. The "insecure attachment" strategies group showed some evidence of positive association with $\mathrm{TSH}$ $\left(R^{2}=0.250\right)$. ACTH was not found correlated with any type of attachment. No explanatory model could be derived for type C, resistant attachment strategies (Fig.1).

\section{DISCUSSION}

Associations between neuro-endocrine and metabolic indicators and attachment strategies were explored in a convenience sample of pre-pubertal obese children from a child obesity clinic. Detailed somatic and behavioral measurements of the child's development and family functioning were collected.

Using multivariable analysis, we found evidence of the association between avoidant attachment strategies (type A) with higher TSH levels and lower cortisol levels. On the other hand, secure attachment strategies (type B) was associated with both the presence of laboratorial evidence of hypothyroidism and higher BMI percentile.

When investigating associations between metabolic indicators and attachment strategies, the role of family functioning and gender should be taken into account. Therefore, we investigated the role of, and interactions between, several biological and environmental factors to see if any specific sub-groups could be identified which may benefit for further description and specific treatment strategies. Type A strategies were found to exhibit a negative, strong association with cortisol levels $(\beta=-0.015$; $p=0.036 ; R^{2}=0.352$ ). This finding offers evidence of an increased risk for dysfunctional HPA-axis in children that score high in type A attachment strategies.

As previously reported, ${ }^{10}$ insecure attached infants (Berkeley system) have been found to display high cortisol levels after a stressful stimulus. This possibility remains and it seems to be the result of different classification procedures, notwithstanding the fact that this finding was not independently validated by other researchers. ${ }^{29,30}$ The high activation of the attachment system of insecure children may not terminate soon after its reunion with the primary caregiver, because the child is unable to use effectively the attachment figure for its regulation, making it difficult for a state of homeostasis to be reached. ${ }^{15}$

Other explanation for these findings is that elevation of cortisol is associated with the presence of a concurrent affective disorder. ${ }^{9}$ On the other hand, cortical suppression could be due to a pattern of stress habituation over time, a pattern that increases the risk of difficulties in emotional and behavioral regulation; equally, reduced stress responsiveness may emerge as a result of genetic factors, or GxE interactions. ${ }^{31}$ These differing patterns may in part reflect adaptations of the HPA axis to different periods of onset and chronicity, and differential genetic susceptibility. Confounders, such as depression, which is a frequently observed comorbidity, may account for some of the reported differences. ${ }^{32}$ It is of mention the lack of depressive symptoms investigation was a handicap, but it was beyond the scope of the present study. "Roots of Early

Table 3 - Adjusted association between attachment strategies and anthropometric, familiar and neuroendocrine variables (multiple linear regression analyses). No associations with resistant attachment (type C) were found.

\begin{tabular}{lcccc}
\hline & Associated variables & $\beta$-estimate $(95 \%$ Cl) & $p$-value & $R^{2}$ \\
\hline Avoidant attachment & Cortisol & $-0.015(-0.028 ;-0.001)$ & 0.036 \\
(type A) & TSH & $0.084(0.015 ; 0.154)$ & 0.021 & 0.352 \\
Secure attachment & Hypothyroidism & $0.207(0.092 ; 0.321)$ & 0.002 \\
(type B) & BMI percentile & $0.291(0.104 ; 0.477)$ & 0.004 \\
"Insecure attachment" & TSH & $0.128(0.000 ; 0.256)$ & 0.050 \\
& ACTH & $-0.011(-0.025 ; 0.002)$ & 0.087 & 0.250 \\
\hline
\end{tabular}

Variables in the models: gender, BMI percentile, family functioning classification, hypothyroidism, cortisol, ACTH, TSH.

ACTH: adrenocorticotropic hormone; BMI: body mass index; Cl: confidence interval; TSH: thyroid-stimulating hormone. 
A

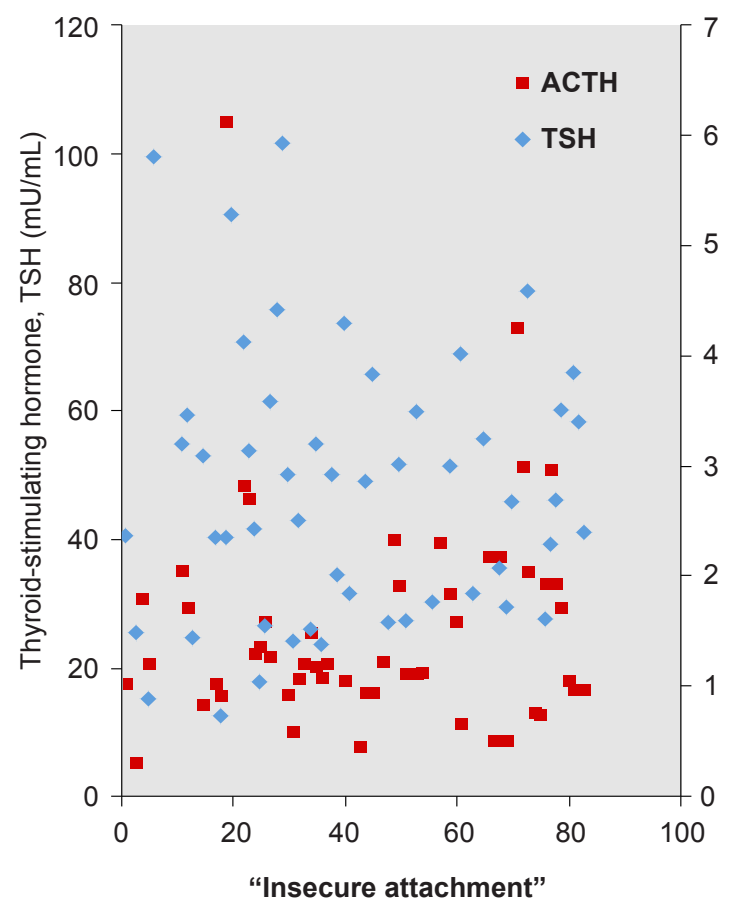

B

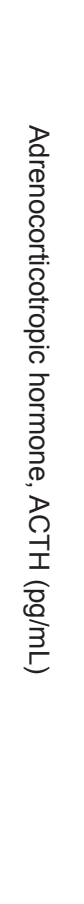

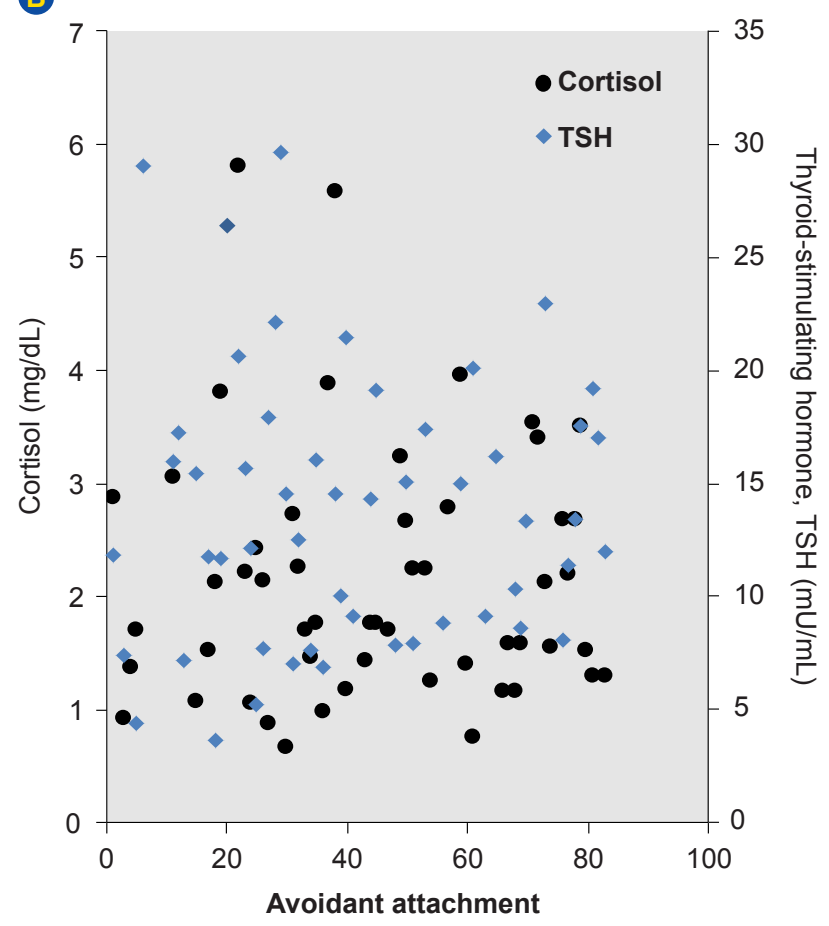

Figure 1 - Associations between insecure (A) and avoidant $(B)$ attachment strategies and hormones of the hypothalamic-pituitary and the hypothalamic-pituitary-adrenal axis, relevant in the adjusted multivariate models

Obesity"19 project explored depressive symptomatology and other comorbidities in a larger sample and this data will be submitted for publication subsequently.

It seems that childhood maltreatment may lead to atypical responsiveness of the HPA axis to stress, which in turn predisposes to psychiatric vulnerability in later life. ${ }^{31}$ While there is general agreement around this broad principle, the putative mechanisms of how dysregulation of the HPA axis might mediate the link between stress and psychopathology and the precise nature of any interaction remains less clear. ${ }^{32}$ It is possible that diminished cortisol responsiveness may emerge if early chronic stress leads to an initial hyper-activation of the HPA system which then progresses over time to a state of hyporeactivity, as a form of adaptation following sustained exposure to ACTH. ${ }^{33}$

In this study, HPA-axis activity was not assessed in response to a stressor given the ethical and practical implications of pharmacological challenge tests with children. As ACTH was not found altered in the explored models, cortisol changes may reflect differences in perceived acute stress which were not considered in the present study. Future studies that assess both measures simultaneously may reveal more differentiated results.

This study has the strengths of obtaining accurate biological and psychometric measurements, using validated instruments on a homogeneous sample of obese, pre-pubertal children for adjusted, multivariable analysis of associations. It has the limitation of using a rather small, convenience sample of children, based on a reference outpatient clinic for obesity, where most of the children have BMI above the $97^{\text {th }}$ percentile. In spite of being a common distribution in non-clinical populations, ${ }^{28}$ the small number of children affects mostly the power to identify significant associations with biological and psychometric variables alike. Therefore, the significant associations found in this sample should be considered as reliable. The small discriminant coefficients $\left(R^{2}\right)$ for the models point out the multifactorial nature of the attachment strategies. Some of the etiological factors have not been collected and others were not found significant due to the sample size. It is impossible to determine the direction of the bias (if any) due to analyzing only those children for whom it was possible to collect all relevant information.

It is well known and accepted that the negative feedback system is essential in recovery from stressful situations and that a balanced stress recovery system that promotes homeostasis is of great importance. Presumably, an insecure attachment relationship does not facilitate adequate termination of the stress reaction. Now, this lack of homeostasis could put the child at metabolic and developmental risk, as long term negative outcomes have been shown to result from both insecure attachment ${ }^{35-37}$ and childhood obesity. It should be noted, however, that the presently reported associations are merely correlational, and that the mechanisms underlying them need elaboration. In obese infants, these associations remain uncharted. ${ }^{28}$

\section{CONCLUSIONS}

These findings suggest that there may be commonalities in the regulation of HPA- and HPT-axes and/or communication between the axes. A common factor, such as developmental processes associated with 
development of the type A attachment strategies, may be important in a linkage between the two axes. Furthermore, the correlation between the HPA and HPT axis may indicate that activity of one axis alters the activity of the other axis. As mentioned above, previous work has demonstrated that glucocorticoids, the end product of HPA axis activation, can inhibit the HPT axis. ${ }^{38}$ This study supports this proposition, i.e., that lower cortisol may be associated with higher TSH levels.

The meaning of this for developing differentiated treatment approaches remains to be explored. Processes involved in development of the type A attachment strategy appear to be associated with effects on the regulatory mechanisms of the HPT axis. Indirectly this clear demarcation of the metabolic profile and attachment strategy is a validation of this Portuguese instrument for assessing attachment, but the study should be repeated using other measures of attachment strategy in this age group.

\section{REFERENCES}

1. Bowlby J. Attachment and Loss. New York: Basic Books; 1982.

2. Kerns KA, Brumariu LE. Is insecure parent-child attachment a risk factor for the development of anxiety in childhood or adolescence? Child Dev Perspect. 2014; 8:12-7.

3. Fonagy P, Gergely G, Jurist E, Target M. Affect regulation, mentalization, and the development of the self. New York: Other Press; 2002.

4. Cassidy J, Jones JD, Shaver PR. Contributions of attachment theory and research: a framework for future research, translation, and policy. Dev Psychopathol. 2013;25:1415-34.

5. Oskis A, Loveday C, Hucklebridge F, Thorn L, Clow A. Anxious attachment style and salivary cortisol dysregulation in healthy female children and adolescents. J Child Psychol Psychiatry 2011;52:111-8.

6. Patterson ZR, Abizaid A. Stress induced obesity: lessons from rodent models of stress. Front Neurosci. 2013;24:130.

7. O'Connor T, Byrne J. Attachment measures for research and practice. Child Adolesc Ment Health. 2007;12:187-92.

8. Spangler G, Zimmermann P. Attachment representation and emotion regulation in adolescents: a psychobiological perspective on internal working models. Attach Hum Dev. 1999;1:270-90.

9. Tarullo A, Gunnar M. Child maltreatment and the developing HPA axis. Horm Behav. 2006;50:632-9.

10. Spangler G, Maier U, Geserick B, von Wahlert A. The influence of attachment representation on parental perception and interpretation of infant emotions: A multilevel approach. Dev Psychobiol. 2010;52:411423.

11. Hutt R, Buss K, Kiel E. Caregiver protective behavior, toddler fear and sadness, and toddler cortisol reactivity in novel contexts. Infancy. 2013;18:708-28.

12. Meaney M. Maternal care, gene expression, and the transmission of individual differences in stress reactivity across generations. Annu Rev Neurosci. 2001;24:1161-92.

13. Ouellet-Morin I, Boivin M, Dionne G, Lupien S, Arsenault L, Barr R, et al. Variations in heritability of cortisol reactivity to stress as a function of early familial adversity among 19-month-old twins. Arch Gen Psychiatry.2008;65:211-8.

14. Francis LA, Granger DA, Susman EJ. Adrenocortical regulation, eating in the absence of hunger and BMl in young children. Appetite. 2013;64:32-8.

15. Gander M, Buchheim A. Attachment classification, psychophysiology and frontal EEG asymmetry across the lifespan: a review. Front Hum Neurosci. 2015; 9:79.

16. Kiel EJ, Buss KA. Toddler inhibited temperament, maternal cortisol reactivity and embarrassment, and intrusive parenting. J Fam Psychol. 2013;27:512-7.

17. Santos N, Costa P, Ruano D, Macedo A, Soares M, Valente J, et al. Revisiting thyroid hormones in schizophrenia. J Thyroid Res.

\section{PROTECTION OF HUMANS AND ANIMALS}

The authors declare that the procedures were followed according to the regulations established by the Clinical Research and Ethics Committee and to the Helsinki Declaration of the World Medical Association.

\section{DATA CONFIDENTIALITY}

The authors declare having followed the protocols in use at their working center regarding patient's data publication.

\section{CONFLICTS OF INTEREST}

The authors declare that there are no conflicts of interest.

\section{FUNDING SOURCES}

Financial support by FCT, SFRH/SINTD/60115/2009, FSE-UE.

2012;569147:15

18. Holsboer F, Ising M. Central $\mathrm{CRH}$ system in depression and anxietyevidence from clinical studies with $\mathrm{CRH} 1$ receptor antagonists. Eur J Pharmacol. 2008;583:350-7.

19. Pinto I, Calhau C, Coelho R. Childhood obesity: the role of family factors, depressive symptoms and anxiety levels. Int J Obes. 2011; 35,1010.

20. Soares I. Relações de vinculação ao longo do desenvolvimento. Teoria e avaliação. Braga: Psiquilibrios; 2007.

21. Main M, Solomon J. Discovery of an insecure-disorganized/disoriented attachment pattern. In: Brazelton T, Yogman, M, editors. Affective development in infancy. Westport: Ablex Publishing; 1986. p.95-124.

22. Crittenden P. A dynamic-maturational model of attachment. Aust $\mathrm{N} \mathrm{Z} \mathrm{J}$ Fam Ther. 2006; 27: 105-115.

23. Kozlowska K, Scher S, Williams L. Patterns of emotional-cognitive functioning in pediatric conversion patients: implications for the conceptualization of conversion disorders. Psychosom Med. 2011;73:775-88.

24. Olson D. Faces III. Minnesota: Family Social Science; 1985.

25. Curral R, Dourado F, Roma Torres A, Barros H, Pacheco Palha A, Almeida L. Coesão e adaptabilidade familiares numa amostra portuguesa: estudo com o Faces III. Psiquiatria Clín. 1999;20:213-7.

26. BarlowSE. Expert committee recommendations regarding the prevention, assessment, and treatment of child and adolescent overweight and obesity: summary report. Pediatrics. 2007;120:S164-S192.

27. O'Brien S, Holubkov R, Reis E. Identification, evaluation, and management of obesity in an academic primary care center. Pediatrics. 2004;114:2 e154-9.

28. Bar-Haim Y, Lamy D, Pergamin L, Bakermans-Kranenburg MJ, van IJzendoorn $\mathrm{MH}$. Threat-related attentional bias in anxious and nonanxious individuals: a meta-analytic study. Psychol Bull. 2007;133:124.

29. Doom JR, Gunnar MR. Stress physiology and developmental psychopathology: past, present, and future. Dev Psychopathol. 2013;25:1359-73.

30. Goldberg S, Levitan R, Leung E, Masellis M, Basile VS, Nemeroff CB, et al. Cortisol concentrations in 12- to 18-month-old infants: stability over time, location, and stressor. Biol Psychiatry. 2003;54:719-26.

31. Van Goozen SHM, Fairchild G. How can the study of biological processes help design new interventions for children with severe antisocial behavior? Dev Psychopathol. 2008; 20:941-973.

32. Newport DJ, Heim C, Bonsall R, MillerAH, Nemeroff CB. Pituitary-adrenal responses to standard and low-dose dexamethasone suppression tests in adult survivors of child abuse. Biol Psychiatry. 2004;55:10-20.

33. Herman JP. Neural control of chronic stress adaptation. Front Behav Neurosci. 2013; 7:61.

34. Sturge-Apple ML, Davies PT, Cicchetti D, Manning LG. Interparental 
violence, maternal emotional unavailability and children's cortisol functioning in family contexts. Dev Psychol. 2012;48:237-49.

35. Hillman JB, Dorn LD, Loucks TL, Berga SL. Obesity and the hypothalamic-pituitary-adrenal axis in adolescent girls. Metabolism. 2012; 61:341-8.

36. Gungor N. Overweight and Obesity in Children and Adolescents. J Clin Res Pediatr Endocrinol. 2014;6:129-43.
37. Dockray S, Susman E, Dorn L. Depression, cortisol reactivity and obesity in childhood and adolescence. J Adolesc Health. 2009;45:344-50.

38. Lobotková D, Staníková D, Staník J, Cervenová O, Bzdúch V, Tichá L. Lack of association between peripheral activity of thyroid hormones and elevated TSH levels in childhood obesity. J Clin Res Pediatr Endocrinol. 2014;6:100-4. 